\title{
Epac activation initiates associative odor preference memories in the rat pup
}

\author{
Matthew T. Grimes, ${ }^{1}$ Maria Powell, ${ }^{1}$ Sandra Mohammed Gutierrez, ${ }^{1}$ \\ Andrea Darby-King, ${ }^{1}$ Carolyn W. Harley, ${ }^{2}$ and John H. McLean ${ }^{1}$ \\ ${ }^{1}$ Division of BioMedical Sciences, ${ }^{2}$ Department of Psychology, Memorial University of Newfoundland, St. John's, \\ Newfoundland, A1B 3V6 Canada
}

\begin{abstract}
Here we examine the role of the exchange protein directly activated by cAMP (Epac) in $\beta$-adrenergic-dependent associative odor preference learning in rat pups. Bulbar Epac agonist (8-pCPT-2-O-Me-cAMP, or 8-pCPT) infusions, paired with odor, initiated preference learning, which was selective for the paired odor. Interestingly, pairing odor with Epac activation produced both short-term (STM) and long-term (LTM) odor preference memories. Training using $\beta$-adrenergic-activation paired with odor recruited rapid and transient ERK phosphorylation consistent with a role for Epac activation in normal learning. An ERK antagonist prevented intermediate-term memory (ITM) and LTM, but not STM. Epac agonist infusions induced ERK phosphorylation in the mitral cell layer, in the inner half of the dendritic external plexiform layer, in the glomeruli and, patchily, among granule cells. Increased CREB phosphorylation in the mitral and granule cell layers was also seen. Simultaneous blockade of both ERK and CREB pathways prevented any long-term $\beta$-adrenergic activated odor preference memory, while LTM deficits associated with blocking only one pathway were prevented by stronger $\beta$-adrenergic activation. These results suggest that Epac and PKA play parallel and independent, as well as likely synergistic, roles in creating CAMP-dependent associative memory in rat pups. They further implicate a novel ERK-independent pathway in the mediation of STM by Epac.
\end{abstract}

Rodents learn maternal odors to locate the dam (Logan et al. 2012). Odors paired with stimuli mimicking maternal care are associatively acquired through the pairing of odor activation (conditioned stimulus, CS) and activation of the noradrenergic locus coeruleus (unconditioned stimulus, UCS) (Moriceau et al. 2009; Raineki et al. 2010; Landers and Sullivan 2012). Direct stimulation of $\beta$-adrenergic receptors in the olfactory bulb concomitant with novel odor is both necessary and sufficient to initiate odor preference learning (Sullivan et al. 2000). Early odor preference learning depends causally on activation of the cAMP (Cui et al. 2007), PKA (Grimes et al. 2012), and CREB (McLean et al. 1999; Yuan et al. 2003) pathway, which has been implicated in multiple forms of mammalian associative learning (Lamprecht et al. 1997; Silva et al. 1998; Alberini 1999; Josselyn and Nguyen 2005).

Recently, an alternate pathway for cAMP signaling effects, exchange protein activated by cAMP (Epac), has found to play various roles in neural plasticity. Zhong and Zucker (2005) demonstrated Epac-initiated long-term facilitation of glutamate release from the crayfish neuromuscular junction (see also Cheung et al. 2006 for presynaptic facilitation in Drosophila). In mammalian systems, Gelinas et al. (2008) demonstrated that while Epac activation did not change basal synaptic transmission in hippocampal slices, it extended long-term potentiation (LTP) duration in conjunction with a weak LTP protocol.

Ouyang et al. (2008) found joint application of a PKA and Epac agonist rescued contextual fear retrieval deficits in norepinephrine-deficient mice, although neither agonist alone sufficed. Ma et al. (2009) demonstrated that infusion of an intrahippocampal Epac agonist enhanced weak contextual fear memory and overcame impairment associated with PKA inhibition, but a high dose Epac agonist was ineffective. In cultured hippocampal

Corresponding author: john.mclean@med.mun.ca

Article is online at http://www.learnmem.org/cgi/doi/10.1101/lm.037101.114. neurons, however, Epac2 (one of the two genes that encode Epac) appears to promote synaptic depression and remodeling rather than potentiation (Woolfrey et al. 2009). Most recently, Yang et al. (2012) found Epac null mutant mice failed to display hippocampal tetanus-induced LTP, while long-term depression was intact, and failed to learn spatial locations in the water maze, while visual platform learning was intact. Social interaction was also reduced. The Epac null mutant deficits cooccurred with an increase in miR-124 expression and a loss of normal Zif268 activation (miR-124 binds to and inhibits Zif268 translation). Zif268 (or early growth factor 1 , egr1) is a transcriptional factor important in synaptic transmission and cognition (Bozon et al. 2003; Renaudineau et al. 2009). Suppression of miR-124 restored normality in all measures. A study of memory amelioration by melatonin also found Epac and miR-124 modulation associated with improvement (Wang et al. 2013). In contrast, another recent study reported Epac activation in the nucleus accumbens interfered with conditioned place preference learning (Park et al. 2014). In broader learning and memory contexts, changes in Epac regulation have been implicated in the underpinnings of Alzheimer's disease (McPhee et al. 2005; Zaldua et al. 2007; Grandoch et al. 2010), schizophrenia (Kelly et al. 2009), and autism (Srivastava et al. 2012).

To further characterize the roles of Epac in learning and memory, the present experiments assess Epac activation in the well-characterized cAMP-dependent associative mammalian learning model, odor preference learning in the rat pup. We find Epac activation alone paired with odor initiates and promotes

\footnotetext{
C 2015 Grimes et al. This article is distributed exclusively by Cold Spring Harbor Laboratory Press for the first 12 months after the full-issue publication date (see http://learnmem.cshlp.org/site/misc/terms.xhtml). After 12 months, it is available under a Creative Commons License (AttributionNonCommercial 4.0 International), as described at http://creativecommons .org/licenses/by-nc/4.0/.
} 
associative odor preference learning. Furthermore, the profile of agonist and antagonist effects on memory subtypes suggests that multiple Epac mechanisms coordinate the acquisition and expression of early odor preference memories. Normal odor preference learning is stimulated and supported by cAMP activation of both PKA and Epac intracellular pathways.

\section{Results}

\section{Role of Epac in early odor learning}

We examined the possibility that Epac influences early odor preference memory through bulbar infusions using the very selective agonist for Epac, 8-pCPT (Enserink et al. 2002; Christensen et al. 2003; Ster et al. 2007; Ma et al. 2009). A one-way ANOVA $\left(F_{(4,26)}=7.412, P=0.0004\right)$ and Dunnett's post hoc analysis $\left.{ }^{* *} P<0.01\right)$ revealed that the activation of bulbar Epac in the presence of odor, even in the absence of any $\beta$-adrenoceptor activation, resulted in the generation of 24-h odor preference memory using all agonist concentrations examined (Fig. 1A). This demonstrates that cAMP can activate Epac to generate odor preference memory and that activating bulbar Epac results in a similar pattern as activating bulbar PKA (Grimes et al. 2012). One-way ANOVA $\left(F_{(2,17)}=8.482, P=0.0034\right)$ revealed that the Epac/ERK pathway also facilitates STM since Epac activation via 8-pCPT infusion produces 3-h memory, similar to $2 \mathrm{mg} / \mathrm{kg}$ Iso UCS (a learning control), and in contrast to the nonlearning saline control (Fig. 1B).

We examined the possibility that Epac activation could cause generalized activation within the olfactory bulb such that any odor tested after training would show odor preference in the pup. When we tested that theory, we found that following intrabulbar Epac activation that pups trained to peppermint and tested to peppermint odor $24 \mathrm{~h}$ later spent significantly more time over the peppermint-scented bedding compared with pups trained to peppermint odor and tested with orange odor (Student unpaired $t$-test, $\left.t_{(10)}=3.674, P=0.0043\right)$. A similar result was observed when the pups were trained to orange odor and tested with orange versus pups trained to orange and tested with pepper- mint (Student $t$-test, $t_{(10)}=2.761, P=0.0201$ ) as shown in Figure $1 C$. These results suggest that Epac activation-mediated odor preference learning is specific only to the trained odor and does not generalize to other odors.

In the final experiment using the Epac agonist, we addressed whether bulbar infusion of 8-pCPT paired with odor activates both ERK and CREB in the olfactory bulb, two candidate mediators of Epac effects. We utilized an intraanimal approach by infusing the Epac agonist 8-pCPT into one olfactory bulb and vehicle into the other bulb $30 \mathrm{~min}$ prior to odor exposure, followed by immunohistochemical examination of pCREB and pERK $10 \mathrm{~min}$ after training. On qualitative examination, it appeared that the most striking change in pERK was in the deep half of the external plexiform layer where the secondary dendrites of mitral cells are located (Fig. 2A). For quantitation, optical density of staining in the medial portion of the external plexiform layer ipsilateral and contralateral to the Epac agonist infusion was obtained while optical density in the olfactory nerve layer was used as control to determine relative optical density. A paired Student $t$-test showed that the Epac agonist induced significant $\left(t_{(4)}=5.134, P=0.007\right)$ increases in pERK compared with the control side (Fig. 2B). Similarly, qualitative analysis suggested the mitral cell layer showed changes in pCREB expression between the two sides (Fig. 2C). Indeed, quantitative analysis using relative optical density showed that pCREB was significantly increased in the mitral cell layer $\left(t_{(4)}=7.217, P=0.002\right)$ ipsilateral to 8-pCPT infusion 10 min after training (Fig. 2D).

Measurement of pERK in learning versus nonlearning pups To assess whether the candidate Epac/ERK pathway had a role in normal $\beta$-adrenoceptor-mediated odor preference memory we measured the phosphorylation of ERK in the olfactory bulbs of learning and nonlearning animals using Western blots. ERK expresses two bands: ERK1 and ERK2 at $\sim 44$ and $42 \mathrm{kDa}$, respectively (Fig. 3E-H). Repeated-measures ANOVAs (Fig. 3A: $F_{(6,24)}=10.546$, $P<0.0001$; Fig. 3B: $\left.F_{(4,16)}=3.264, P=0.0388\right)$ revealed there was a significant difference in ERK1 phosphorylation between learning and nonlearning animals compared with the nonlearning
A

Epac agonist: 24 Hour Memory

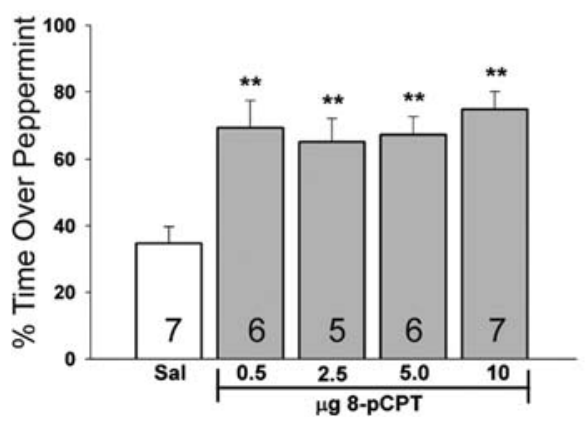

B Epac agonist: 3 Hour Memory

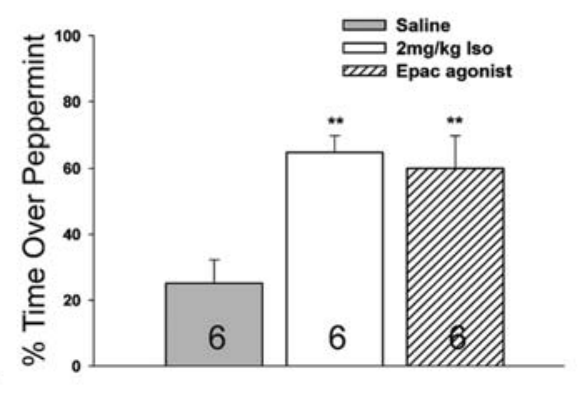

Epac agonist Odor Discrimination test: 24 Hour Memory

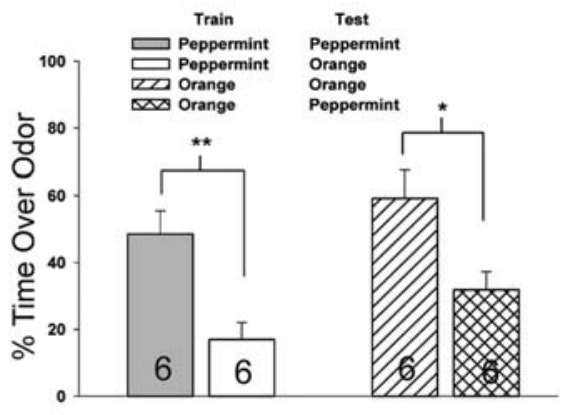

Figure 1. Epac activation is a sufficient UCS to generate STM and LTM. (A) Olfactory bulb infusion of 8-pCPT (Epac agonist) 20 min before odor exposure generates 24-h LTM even in the absence of noradrenergic activation. No inverted U-curve response occurred with different concentrations of the drug, which was also seen with the activation of another CAMP target, PKA, as the UCS (Grimes et al. 2012). (B) Intrabulbar activation of Epac (5 $\mu \mathrm{g}$ 8-pCPT) is sufficient to produce 3-h STM. (C) Activation of Epac (5 $\mu \mathrm{g}$ 8-pCPT) 20 min before training resulted in odor-specific learning rather than generalized preference to a presented odor. That is, pups trained with one odor demonstrated the ability to discriminate between the learned and nonlearned odors $24 \mathrm{~h}$ later. Data are expressed as mean \pm SEM. $\left({ }^{* *}\right) P<0.01,\left({ }^{*}\right) P<0.05$. The odor preference test required a choice of either odor (peppermint- or orange-scented bedding) or no odor (normal-scented bedding). $n$ values are shown within the column for each group. 

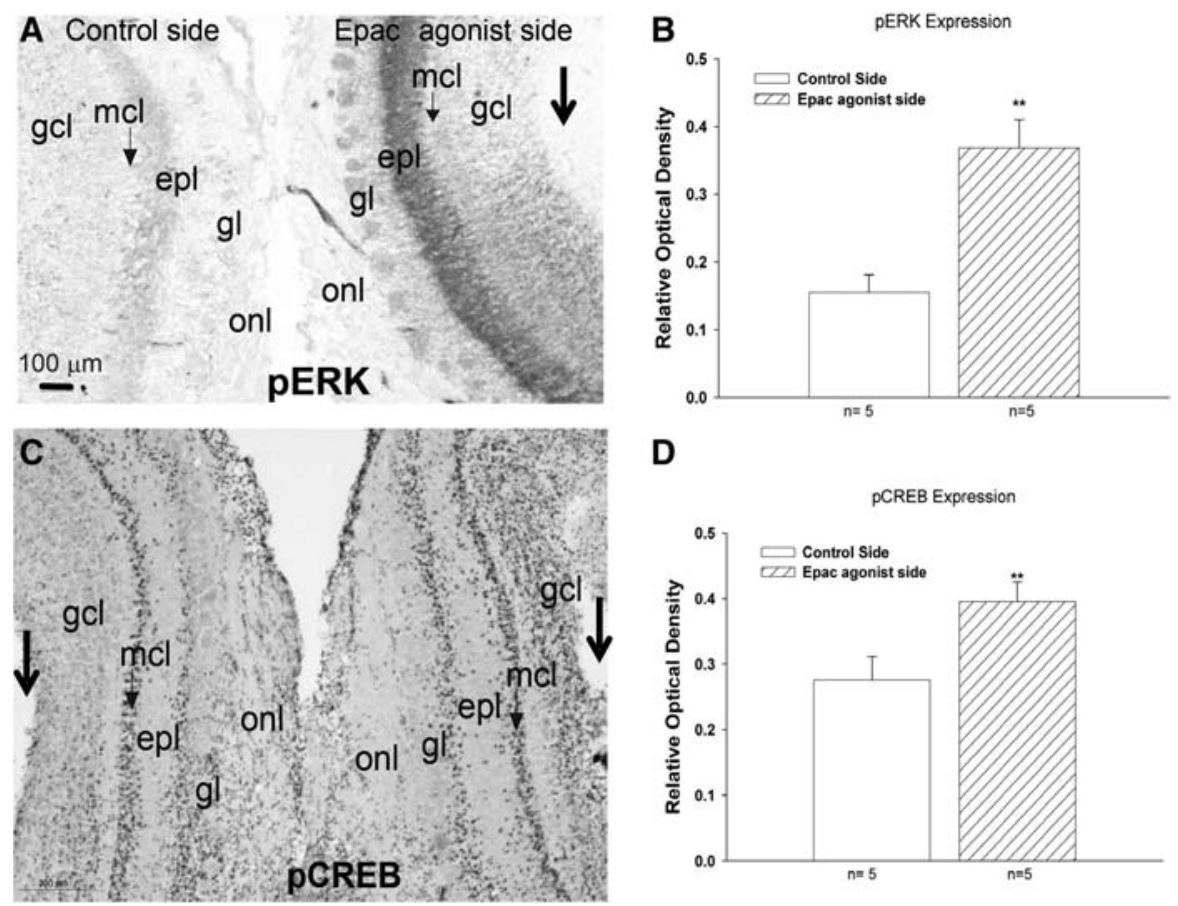

D

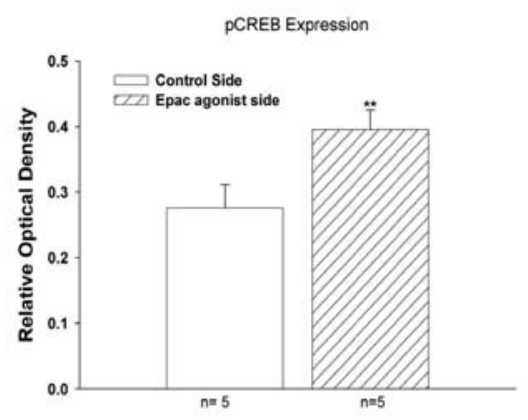

Figure 2. Immunohistochemistry was used to visualize pERK or pCREB expression in the olfactory bulb. Unilateral infusion of 8-pCPT (Epac agonist) into the olfactory bulb 20 min prior to odor training results in increased pERK in several layers $(A)$. The external plexiform layer was measured and found to be significantly darker than vehicle side $(B)$. Increased pCREB activation was also observed in several layers $(C)$ and density measurements within the mitral cell layer was significant $(D)$ compared with the vehicle treated olfactory bulb. Large arrows indicate sites of the cannula track. Data in $B$ and $D$ are expressed as mean \pm SEM. Paired $t$-tests were used to evaluate differences in relative optical density staining between vehicle- and 8-pCPT-infused olfactory bulbs. $\left.{ }^{* *}\right) P<0.01$. (epl) External plexiform layer, ( $\mathrm{gcl}$ ) granule cell layer, $(\mathrm{gl})$ glomerular layer, $(\mathrm{mcl})$ mitral cell layer, (onl) olfactory nerve layer.

saline control (normalized to 100\%). A post hoc Dunnett's test revealed that learning animals $(2 \mathrm{mg} / \mathrm{kg}$ Iso + odor) had a significant $\left({ }^{*} P<0.05,{ }^{* *} P<0.01\right)$ increase in the phosphorylation of ERK1 immediately after learning relative to the nonlearning saline controls (Fig. 3A). This increase remains elevated for $10 \mathrm{~min}$ after learning, but then returns to control levels $30 \mathrm{~min}$ after learning where it remains (Fig. 3B). However, this differed from nonlearning animals given supraoptimal UCS activation $(6 \mathrm{mg} /$ $\mathrm{kg}$ Iso + odor) where the significant increase in the phosphorylation of ERK1 occurred immediately after learning (Fig. 3A, sacrifice immediately after $10 \mathrm{~min}$ of odor exposure), remained elevated for $10 \mathrm{~min}$ (Fig. 3A, sacrifice $20 \mathrm{~min}$ after first odor exposure), and then became elevated again $60 \mathrm{~min}$ after odor training (Fig. 3B, sacrifice $70 \mathrm{~min}$ after first odor exposure). There was also a difference in the phosphorylation of ERK2, as revealed with repeated-measures ANOVAs (Fig. 3C: $F_{(6,24)} P=7.182, \quad P=$ 0.0002; Fig. 3D: $\left.F_{(4,16)}=4.134, P=0.0173\right)$ where a significant difference between learning and nonlearning animals was shown compared with the nonlearning saline control. A post hoc Dunnett's test $\left({ }^{*} P<0.05,{ }^{* *} P<0.01\right)$ revealed that learning animals $(2 \mathrm{mg} / \mathrm{kg}$ Iso + odor) had a significant increase in the phosphorylation of ERK2 immediately after odor training relative to the nonlearning saline control (Fig. 3C, $10 \mathrm{~min}$ after initial odor exposure). This increase in phosphorylation was not present 10 min later and remained at control levels thereafter (Fig. 3D, 20 min). However, this again differed from nonlearning animals given supraoptimal UCS ( $6 \mathrm{mg} / \mathrm{kg}$ Iso), where the significant increase in the phosphorylation of ERK2 occurred immediately after learn- ing, stayed elevated for $10 \mathrm{~min}$ (Fig. 3C, $20 \mathrm{~min}$ ) and then became elevated again $60 \mathrm{~min}$ after learning (Fig. 3D, $70 \mathrm{~min}$ ).

\section{Effect of ERK inhibition on odor preference memories}

We further explored the role of the ERK pathway in odor preference learning by inhibiting bulbar ERK before odor training took place. We found that inhibiting ERK had no effect on 3-h STM (one-way ANOVA, $\left.F_{(4,25)}=19.424, P<0.0001\right)$. A post hoc Dunnett's test $\left({ }^{* *} P<0.01\right)$ revealed that both the learning control $(2 \mathrm{mg} / \mathrm{kg}$ Iso + vehicle infusion + odor) and ERK-inhibited learning animals (2 mg/kg Iso + U0126 infusion + odor) significantly differed from the nonlearning control (saline injection + vehicle infusion + odor). In contrast, ERK-inhibited nonlearning animals $(0 \mathrm{mg} / \mathrm{kg}$ Iso + U0126 infusion + odor and $6 \mathrm{mg} / \mathrm{kg}$ Iso + U0126 infusion + odor) did not differ from the nonlearning control (Fig. 4A).

The examination of 5-h ITM demonstrated a requirement for bulbar ERK activation (one-way ANOVA, $F_{(4,25)}=$ 12.872, $P<0.0001)$. Post hoc Dunnett's test showed, similar to that observed with 3-h memory, the learning control ( $2 \mathrm{mg} / \mathrm{kg}$ Iso + odor) was significantly different $\left({ }^{* *} P<0.01\right)$ from the nonlearning vehicle control $(0 \mathrm{mg} / \mathrm{kg}$ Iso + odor $)$. In contrast to the 3-h memory, the ERK-inhibited groups for 5-h memory showed no difference from the nonlearning control (Fig. 4B). Evaluation of 24-h memory demonstrated a similar result to ITM, where learning was suppressed with the inhibition of bulbar ERK activity (one-way ANOVA, $F_{(4,15)}=59.917$, $P<0.0001)$. A post hoc Dunnett's test $\left({ }^{* *} P<0.01\right)$ revealed that pups that normally learn ( $2 \mathrm{mg} / \mathrm{kg}$ Iso) did not differ from the nonlearning control when ERK was inhibited. However, increased $\beta$-adrenoceptor activation (6 mg/kg Iso), which normally does not induce learning (Langdon et al. 1997; Yuan et al. 2000), facilitated 24-h memory even when ERK was inhibited (Fig. 4C).

\section{Parallel pathways for learning}

It is possible that 24-h LTM was restored even when ERK was inhibited by supranormal $\beta$-adrenoceptor activation through an alternate molecular pathway phosphorylating CREB. Previous work in this laboratory found that inhibiting PKA also disrupts LTM unless supranormal (6 mg/ $\mathrm{kg}$ Iso) $\beta$-adrenoceptor activation is provided, which recruits the phosphorylation of CREB even though PKA is inhibited (Grimes et al. 2012). We hypothesized then that cAMP could also work through the Epac/ERK pathway to drive transcription and LTM formation, as seen here, when PKA is inhibited. Cooperation and compensation between these two pathways would then be occurring reciprocally, with elevated cAMP from supranormal $\beta$-adrenoceptor activation (Cui et al. 2007) working to induce LTM through the PKA pathway while ERK is inhibited.

We examined this possibility for $\beta$-adrenoceptor-mediated odor preference learning by simultaneously inhibiting both the 
A

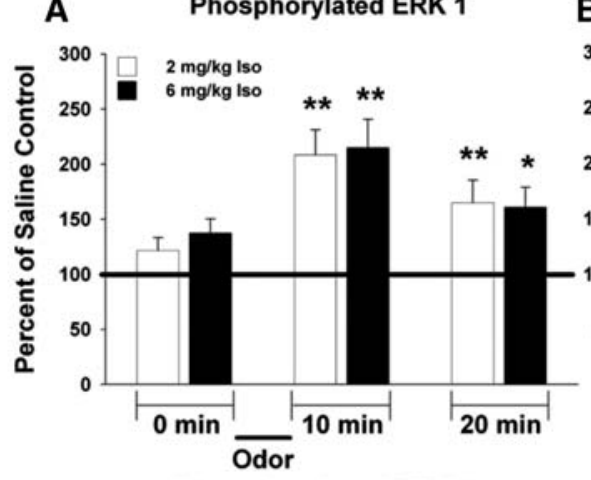

C
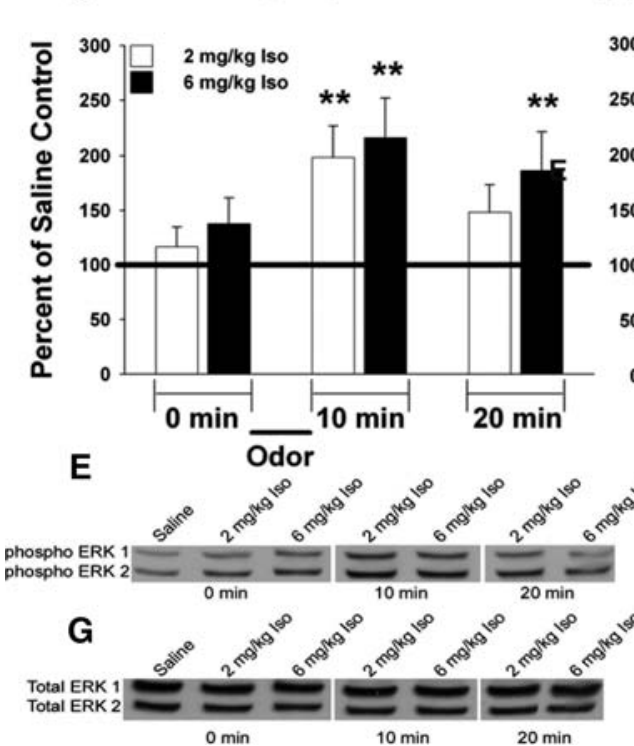

$0 \mathrm{~min}$

\section{B}

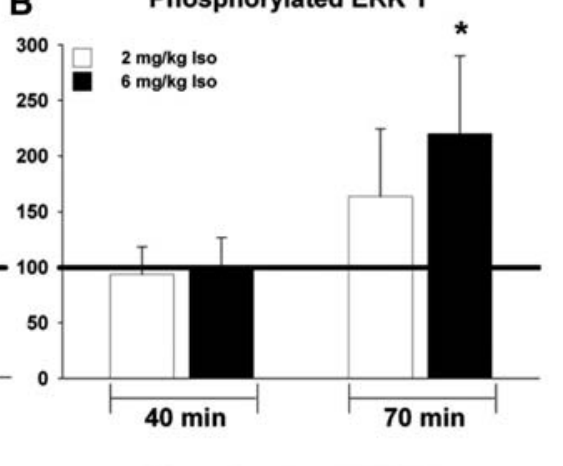

D

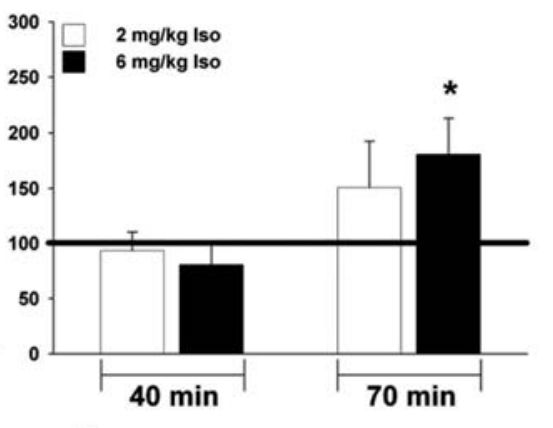

$F$

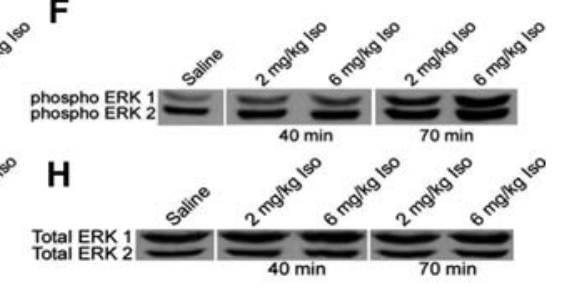

Figure 3. Odor preference learning causes immediate activation of ERK that decays quickly, while nonlearning animals demonstrate two periods of ERK activation. $(A, B)$ The phosphorylation of ERK1 increases immediately after learning and remains elevated for $10 \mathrm{~min}$ in learning animals $(2 \mathrm{mg} / \mathrm{kg} \mathrm{Iso}+$ odor), after which it returns to normal control levels. However, in nonlearning animals $(6 \mathrm{mg} / \mathrm{kg} \mathrm{Iso}+$ odor) the phosphorylation of ERK1 increases at two separate time periods. It increases immediately after learning and remains elevated for $10 \mathrm{~min}$ after which it returns to normal control levels, but then becomes elevated again $1 \mathrm{~h}$ after learning. $(C, D)$ The phosphorylation of ERK 2 increases immediately after learning and returns to normal control levels 10 min later in learning animals. However, in nonlearning animals the phosphorylation of ERK2 increases at two separate time periods. It increases immediately after learning and remains elevated for $10 \mathrm{~min}$ after which it returns to normal control levels, but then becomes elevated again $1 \mathrm{~h}$ after learning. $(E, F)$ A representative immunoblot of phosphorylated ERK1/2 (1:1000, Cell Signaling) under learning ( $2 \mathrm{mg} / \mathrm{kg}$ Iso + odor) and nonlearning (6 mg/ $\mathrm{kg}$ lso + odor) conditions. $(G, H)$ A representative immunoblot of total ERK1/2 (1:1000, Cell Signaling) under learning and nonlearning conditions demonstrates no change in total ERK between conditions and across all time points. $n=5$ for all groups. Data are expressed as phosphorylated ERK normalized to total ERK and as percentage relative to saline nonlearning control ran in the same experiment. Error bars are SEM. $\left({ }^{*}\right) P<0.05,\left({ }^{*}\right) P<0.01$.

PKA and ERK pathways in pups by coinfusion of Rp-cAMPs $(1 \mu \mathrm{L}$, $22 \mathrm{mM}$, PKA inhibitor) and U0126 ( $1 \mu \mathrm{g} / 0.5 \mu \mathrm{L}$, ERK inhibitor) on PND6 prior to odor training followed by odor preference testing at $24 \mathrm{~h}$. A one-way ANOVA $\left(F_{(4,27)}=12.950, P<0.0001\right)$ and post hoc Dunnett's test $\left.{ }^{* *} P<0.01\right)$ revealed no difference between any of the experimental groups and the nonlearning control, even when $\beta$-adrenoceptor activation was increased to supranormal levels (Fig. 4D). This apparently complete blocking of longterm $\beta$-adrenoceptor-mediated odor preference learning suggests that cAMP can work through either the PKA and ERK pathways to generate memory, even under nonphysiological conditions, demonstrating each pathway's ability to compensate in support- ing long-term memory (LTM) plasticity while the other is inhibited.

\section{Discussion}

The present results demonstrate that cAMP-mediated odor preference learning in the rat pup recruits Epac as well as the PKA signaling. The outcomes using an Epac selective agonist and an ERK antagonist further suggest that each of the three forms of memory previously demonstrated in this associative learning model (Grimes et al. 2011) have different requirements for Epac and PKA activation.

\section{LTM and Epac}

Epac activation paired with odor induced a synapse-specific 24 -h protein transcription-dependent odor memory in $6 \mathrm{~d}$ old rat pups. Pups preferred peppermint, but not orange odor, if trained on peppermint or the converse. Epac is known to activate ERK1/2 through recruitment of the Ras-proximate-1 (Rap1) pathway (de Rooij et al. 1998; Kawasaki et al. 1998; Lin et al. 2003; Keiper et al. 2004; Gelinas et al. 2008; Ma et al. 2009). Intrabulbar blockade of ERK activation prevented 24-h odor preference memory consistent with the ability of Epac to activate 24-h memory. Earlier work has documented a selective role for ERK phosphorylation in a variety of long-term mammalian associative memory models (Schafe et al. 1999; Izquierdo et al. 2000; Ohno et al. 2001; Kelly et al. 2003; Zhang et al. 2003, 2004; Eckel-Mahan et al. 2008) including aversive odor learning in older rat pups (Zhang et al. 2003).

A role for ERK activation in $\beta$-adrenoceptor-mediated odor preference learning was established through evaluation of ERK1/2 phosphorylation following the 10 min odor $+\beta$-adrenoceptoractivation training period. Increased phosphorylation of ERK1 and ERK2 was seen immediately after training and at 10 min after training for ERK1 with marginal elevation of ERK2 at the same time point. There was a return to baseline for the remainder of the intervals tested (up to $70 \mathrm{~min}$ after initial odor exposure). This pattern suggests ERK activation normally precedes CREB activation, which is maximally elevated 10 min following training rather than immediately (McLean et al. 1999).

\section{LTM and PKA and Epac interactions}

Previous work from our laboratory demonstrated that direct PKA activation paired with odor produced 24 -h odor preference memory and that there was no inverted- $U$ curve in the doselearning relationship (Grimes et al. 2012). The same pattern was seen here with direct Epac agonist activation. All doses of 

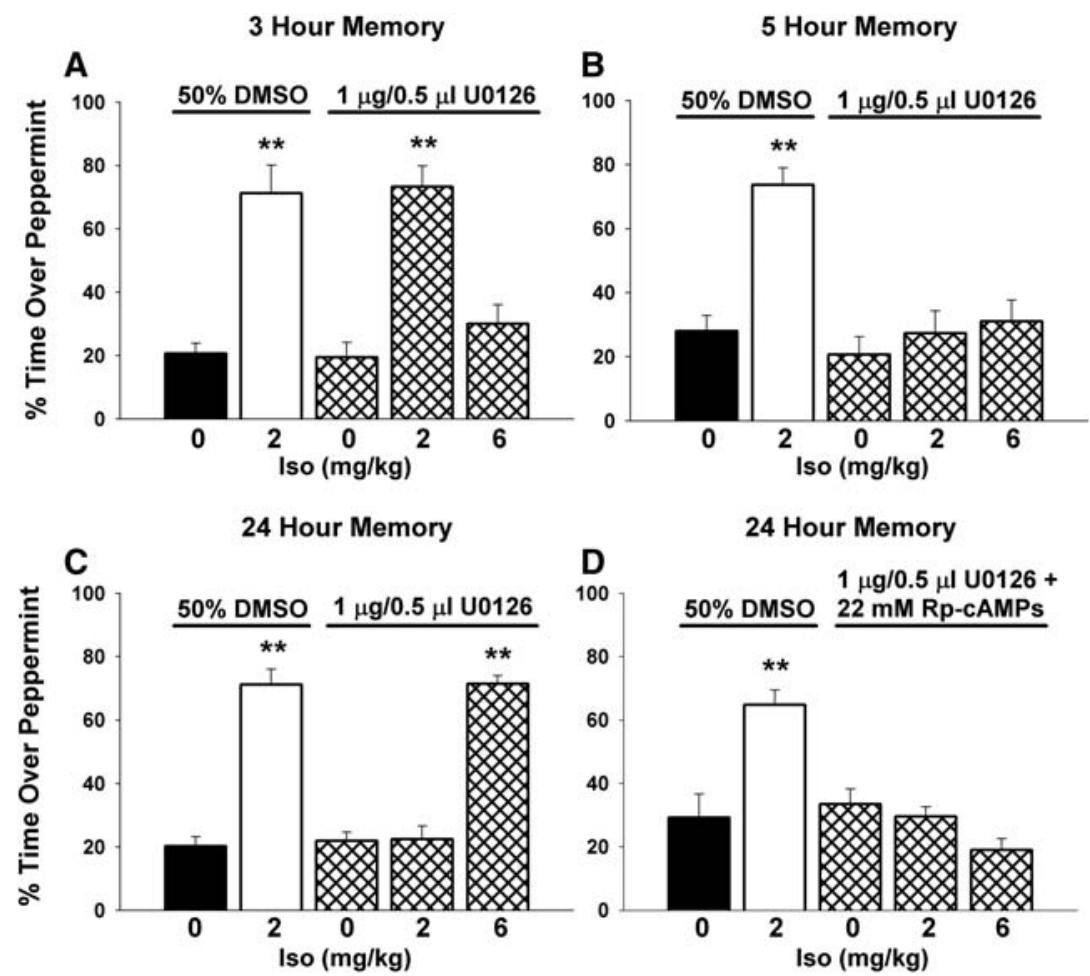

Figure 4. The activation of bulbar ERK is required for 5-h ITM and 24-h LTM, but not 3-h STM. (A) Olfactory bulb infusion of the ERK inhibitor U0126 before learning does not affect 3-h STM formation. This ERK inhibition had no effect on learning $(2 \mathrm{mg} / \mathrm{kg}$ Iso + odor) resulting in a normal inverted U-curve response to isoproterenol (noradrenergic) activation. (B) Olfactory bulb infusion of U0126 before learning causes the inhibition of 5-h ITM formation. This ERK inhibition disrupted normal learning $(2 \mathrm{mg} / \mathrm{kg}$ lso + odor) resulting in ITM being reduced to nonlearning control levels. (C) Olfactory bulb infusion of U0126 before learning also caused the inhibition of 24-h LTM formation. The inhibition of bulbar ERK before learning disrupts normal learning $(2 \mathrm{mg} / \mathrm{kg}$ Iso + odor) and inhibits LTM formation. However, 24-h LTM is restored with increased $\beta$-adrenoceptor activation $(6 \mathrm{mg} / \mathrm{kg}$ lso) suggesting an alternate pathway is involved. (D) When both ERK and PKA pathways are blocked (using U0126 and Rp-cAMPs, respectively) before learning, 24 -h memory is blocked with either normal ( $2 \mathrm{mg} / \mathrm{kg}$ lso) or supraoptimal ( $6 \mathrm{mg} / \mathrm{kg}$ Iso) noradrenergic activation at training. This suggests that when alternate pathways are blocked, learning is difficult or not possible to achieve. Data are expressed as mean \pm SEM. $\left.{ }^{* *}\right) P<0.01$. $n$ values are shown within the columns.

Epac-initiated odor preference learning. These outcomes suggest either PKA or Epac activation suffices for odor learning. However, interference with the ERK pathway or with PKA activation (see Grimes et al. 2012), prevents the acquisition of normal long-term memories for odor preference. This suggests that PKA and Epac are both recruited in odor preference learning and are both required for normal LTM. A similar dependence on coactivation of the two pathways has been reported for the retrieval of contextual fear memories (Ouyang et al. 2008).

In the $\beta$-adrenoceptor-mediated odor preference learning model, it is possible to use a higher dose of the $\beta$-adrenoceptor agonist, isoproterenol $(6 \mathrm{mg} / \mathrm{kg})$, that, because of an inverted U-curve relationship with learning, does not produce preference learning when paired with odor normally (Langdon et al. 1997). With learning impairments, however, induced by suppression of either the PKA or Epac-ERK pathway, the higher dose of isoproterenol restores 24 -h odor preference memory when paired with odor. This suggests that sufficiently strong $\beta$-adrenoceptor activation in the presence of a single cAMP-mediated cascade, whether PKA or ERK-dependent, can activate the intact pathway sufficiently to initiate memory. Here we showed that if both PKA and ERK-dependent pathways are blocked simultaneously no compensation occurs and $\beta$-adrenoceptor-mediated learning is not expressed. This suggests that $\beta$-adrenoceptor-mediated learning requires at least one of these two cascades to be active for long-term associative memory to be initiated.

Previously we examined the pattern of cAMP increases with both optimal and excessive doses of isoproterenol and found that optimal isoproterenol doses, or natural stroking stimuli, paired with odor produced a phasic pattern of peak cAMP activation immediately following the training trial, while an excessive dose produced a steady and sustained rise in cAMP post-training (Cui et al. 2007). We suggested then that stronger recruitment of phosphatases by the rising cAMP pattern led to the learning impairment with the higher isoproterenol dose and the failure to see CREB phosphorylation. This hypothesis was supported by the ability of calcineurin to enable learning when given with the higher dose of isoproterenol (ChristieFougere et al. 2009).

But other mechanisms may also be at work. Since coactivation of both PKA and ERK pathways occurs normally with the optimal dose of isoproterenol and would presumably also occur with a higher dose, there may be antagonistic interactions between the two pathways (Nijholt et al. 2008) with sustained cAMP increases.

Western blots demonstrate that the pattern of ERK1/2 activation is also altered with higher isoproterenol by generating a second activation period $70 \mathrm{~min}$ post-training. While this second activation may be related to the failure to learn at the higher dose, it is also true that a higher isoproterenol dose paired with odor does not produce CREB activation at 10 min (Yuan et al. 2000) while both direct PKA (Grimes et al. 2012) or Epac activation alone paired with odor increase CREB phosphorylation at that time point (present data). Thus the inverted-U curve effects on $\beta$-mediated preference learning are more consistent with an inability to recruit critical nuclear transcription promoting events at the 10 min post-training time point.

\section{Intermediate-term memory (ITM) and Epac}

The ERK antagonist produced a loss of ITM as well as LTM. ITM is a distinctive form of memory both in terms of its time course and in terms of its dependence on protein translation, but not protein transcription (Grimes et al. 2011). While previous evidence demonstrated that a PKA activator could induce ITM, but not STM (Grimes et al. 2012), here we show that a higher level of $\beta$-adrenoceptor activation cannot compensate, failing to restore ITM in the presence of the ERK blockade. This suggests an absolute dependence of intermediate-term translation-dependent memory on the ERK pathway. An absolute requirement for ERK activation in the generation of ITM has also been reported in Aplysia (Sharma et al. 2003). This may be related to ERK recruitment of the translational factors eIF4E, 4EBP1, and ribosomal protein S6 
(Kelleher et al. 2004). It has also been reported that Epac can work through ERK to repress miR-124 and thus facilitate learning (Yang et al. 2012), which is also likely to modulate protein translation.

\section{STM and Epac}

Although STM is robust and reliable when pairing $\beta$-adrenoceptor-activation with odor in rat pups, activation of PKA directly produced long-term, but not STM, consistent with other reports selectively associating activation of the PKA cascade with LTM (Abel and Nguyen 2008). Here Epac activation reliably and robustly produced short-term odor preference memory suggesting Epac is the primary mediator of this form of memory in the rat pup associative learning model.

ERK blockade, however, did not alter STM, a finding that is consistent with a separate Epac-dependent mechanism supporting STM. There are several candidates. As mentioned in the Introduction, Epac can enhance presynaptic release of neurotransmitter. Indeed, Epac enhances Rab3A-RIM1 (proteins involved in transmitter release machinery) interactions through phospholipase $\mathrm{C}$ to potentiate glutamate release in cerebrocortical nerve terminals (Ferrero et al. 2013). Epac also enhances intracellular calcium levels and has been shown to recruit calcium calmodulin kinase II (CAMKII), both of which promote neurotransmitter secretion in other systems (Mani et al. 2014). In early odor learning an initial, but transient, increase in transmitter release is associated with isoproterenol facilitation of $\theta$ burst stimulation in piriform cortex (Morrison et al. 2013), consistent with possible presynaptic support of STM. Other investigators have speculated that CaMKII has a particular role in STM through autophosphorylation and effects on post-synaptic proteins (Miller and Kennedy 1986; Rich and Schulman 1998; Yang and Schulman 1999; Lisman et al. 2002). An Epac scaffolding protein, $\beta$-arrestin, is highly enriched in the olfactory bulb (Attramadal et al. 1992) and $\beta$-arrestin 1 specifically promotes the interaction of Epac and CaMKII (Mangmool et al. 2010) when activated by a $\beta 1$-adrenoceptor agonist to facilitate activation of CaMKII. $\beta 1$-adrenoceptors are selectively involved in the initiation of odor preference learning in rat pups (Harley et al. 2006).

We are investigating a possible role for CaMKII in STM in ongoing experiments. Epac could also increase neurite excitability locally by affecting slow delayed $\mathrm{K}^{+}$rectifier currents (Witkowski et al. 2012; Aflaki et al. 2014).

\section{Temporal and spatial profiles of learning-associated ERK activation in the olfactory bulb}

With the advent of new imaging techniques it is now appreciated that the intracellular actions of cAMP are characteristically constrained both temporally and spatially. In our earlier work on the cAMP temporal profile associated with early odor preference learning we demonstrated a close link between the timing of a phasic profile of cAMP increases and associative memory (Cui et al. 2007; McLean et al. 2009). The maximal activation of ERK immediately following pairing of odor and $\beta$-adrenoceptor-stimulation is congruent with the phasic peak of cAMP at the same time point (Cui et al. 2007).

Intrabulbar 8-pCPT infusion paired with odor produced increased phosphorylation of both ERK and CREB. Increases in ERK and CREB phosphorylation have also been reported following olfactory preference training in the olfactory bulb of the adult fruit bat (Ganesh et al. 2010).

Spatially, the ERK activation pattern revealed by immunohistochemistry is consistent, at least in part, with known scaffolding complexes for Epac and suggests multiple compartments for ERK-mediated effects. Previously pERK had been investigated in the olfactory bulb of young rats deprived of odor, an event associated with pERK down regulation, and then exposed to odor. Initial odor exposure strongly elevated pERK in the cytoplasm of mitral cells and both their lateral and apical dendrites, with darker staining in the inner third of the plexiform layer as seen here and distinct staining in the glomeruli (Mirich et al. 2004). Granule cells also contained pERK. The patterns here were similar. Elevated ERK activation was conspicuous in the glomeruli where mitral cell apical dendrites interact with olfactory sensory nerve input, and in periglomerular interneurons. The inner half of the external plexiform layer where the lateral dendrites of mitral cells interact with granule cell spines was densely stained for pERK as was the mitral cell body layer and patchy clusters of granule cell bodies.

The localization of pERK in areas associated with synaptic contacts is consistent with a role for ERK in modifying contacts or communication in olfactory circuits. Studies investigating ERK activation when arousing stimulation was combined with specific auditory input in auditory cortex suggest the pattern of pERK in dendrites and cells bodies reflects enhancement driven by associative events (Kawai et al. 2013).

Epac could easily mediate dendritic ERK phosphorylation as it is found in post-synaptic density scaffolding complexes like AKAP79/150 in which Epac/PKA/PDE and CaMKII are physically associated (Nijholt et al. 2008). The post-synaptic density AKAP79/150 is enriched in olfactory bulb and other sites implicated in learning and memory (Ostroveanu et al. 2007). Consistent with enrichment in dendrites, Epac has been shown to contribute to the reshaping and maintenance of neuronal connectivity (Penzes et al. 2009; Woolfrey et al. 2009; Srivastava et al. 2012), a likely part of the LTM story.

Our results suggest Epac has a role in inducing both olfactory learning and the three forms of memory investigated. In two recent reports on genetic models of mental dysfunction (Kanellopoulos et al. 2012; Wolman et al. 2014) pharmacological interventions promoting the cAMP/PKA cascade overcome the associated behavioral deficits. Epac activation merits investigation in these models. Both PKA and Epac pathways are likely to act synergistically in cAMP-dependent associative learning more broadly. Epac thus constitutes a novel target for clinical conditions in which learning or memory deficits are a central feature.

\section{Summary}

The present experiments reveal a direct role for Epac in the initiation and support of associative STM, ITM, and LTM. The results are consistent with patterns of effects on other neural systems. These data highlight the rat pup olfactory bulb as a useful and relatively simple mammalian structure in which to unravel the mechanisms of Epac signaling in functionally critical neural plasticity.

\section{Materials and Methods}

All the experiments were conducted on Sprague-Dawley rat pups (Charles River) of both sexes, with no more than one male and one female being used per condition within a litter. The litters were culled to 12 pups on post-natal day 1 (PND1, PND0 = day of birth) and housed with the dam on a 12-h reverse light-dark cycle with food and water available ad libitum. All experiments were approved by the Memorial University Institutional Animal Care Committee.

\section{Western blots}

The examination of the phosphorylation of ERK in learning and nonlearning animals occurred with the decapitation of pups immediately before, immediately after, $10 \mathrm{~min}$ after, $30 \mathrm{~min}$ after, or $60 \mathrm{~min}$ after odor exposure. The olfactory bulbs were removed and frozen on dry ice and stored at $-80^{\circ} \mathrm{C}$ until used. Western 
blots were examined to measure the phosphorylation of ERK (phosphorylated at Thr202/Tyr204 or ERK1/2, and total ERK1/ 2, Cell Signaling Technology) and followed protocols previously described (Cui et al. 2011).

\section{Surgeries}

In other experiments, examination of Epac and ERK was conducted through the infusion of pharmacological agents into the olfactory bulbs. On PND5, pups underwent cannula placement surgery, which started with pups being anesthetized through hypothermia. They were placed in a stereotaxic apparatus in an ice bath and a sagittal incision was made in the scalp from the snout to the lambdoid suture (Rumsey et al. 2001). Holes were drilled over the olfactory bulbs and premade guide cannulae were lowered so they were resting on top of the olfactory bulbs. The cannula consisted of two 6-mm long 26 gauge stainless steel tubes (Small Parts Inc.) separated by $2 \mathrm{~mm}$. The cannulae were secured to the skull through the application of dental acrylic (Lang Dental) anchoring them to an upside down plastic screw (Small Parts Inc.) that was glued to the posterior area of the skull. Pups were sutured and then revived on a heating pad. Bitter Apple biting deterrent (Grannick's Bitter Apple Company) was applied to the sutures and cannula and the pups were placed back with the dam (Grimes et al. 2011).

\section{Drug injections/infusions and odor training}

On PND6, pups were given s.c. injection of the unconditioned stimulus, isoproterenol (Iso, $\beta$-adrenoceptor agonist, Sigma at $2 \mathrm{mg} / \mathrm{kg}$ or $6 \mathrm{mg} / \mathrm{kg}$ ) or saline vehicle $40 \mathrm{~min}$ prior to odor conditioning and placed back with the dam. Twenty minutes prior to odor conditioning, drugs or vehicle were infused into the olfactory bulb.

Conditioning to an odor involved placing the pup on peppermint-scented bedding (300 $\mu \mathrm{L}$ peppermint extract/500 mL bedding) for 10 min (Sullivan et al. 1991; Grimes et al. 2011).

Drug infusions included the following: U0126 (specific MEK inhibitor, Cayman Chemical) was infused at a concentration of $5.3 \mathrm{mM}$ and was dissolved in a vehicle of 50\% DMSO and ACSF (10 mM glucose, $2 \mathrm{mM} \mathrm{CaCl}_{2}, 126 \mathrm{mM} \mathrm{NaCl}, 1.2 \mathrm{mM} \mathrm{MgCl}_{2}$, $25 \mathrm{mM} \mathrm{NaHCO}, 2.5 \mathrm{mM} \mathrm{KCl}, 1.2 \mathrm{mM} \mathrm{NaH}_{2} \mathrm{PO}_{4}, \mathrm{pH}=7.35$ ) (Favata et al. 1998; Roberson et al. 1999; Schafe and LeDoux 2000; Duvarci et al. 2005). Infusion was $0.5 \mu \mathrm{L}$ over $4 \mathrm{~min}$. The infusion cannulae were left in the guide cannulae for an additional 2 min to allow the solution to diffuse throughout the olfactory bulb.

8-pCPT-2'-O-Me-cAMP. 8-pCPT, highly selective Epac agonist (Axxora BioChemicals) (Enserink et al. 2002; Christensen et al. 2003; Ster et al. 2007; Ma et al. 2009) was dissolved in saline. Amount infused over $3 \mathrm{~min}$ was $0.5,2.5$, 5, or $10 \mu \mathrm{g} / 0.5 \mu \mathrm{L} 20 \mathrm{~min}$ before putting the pup over peppermint-scented bedding.

Rp-cAMPs. PKA antagonist, $22 \mathrm{mM}$, dissolved in saline (Sigma) or saline was infused in a $1 \mu \mathrm{L}$ volume into both olfactory bulbs using the same procedure as 8-pCPT described above. The olfactory bulb infusion occurred by lowering a 7-mm 30 gauge stainless steel infusion cannula (Small Parts Inc.), attached to a $10 \mu \mathrm{L}$ Hamilton syringe by polyethylene tubing, into the guide cannula (Grimes et al. 2011). The infusion rate was $0.5 \mu \mathrm{L}$ over $4 \mathrm{~min}$ and the infusion cannula was left in place for $2 \mathrm{~min}$ to allow drug diffusion.

\section{Odor testing}

Pups were tested for odor preference at various times after training including $3 \mathrm{~h}$ later for STM, $5 \mathrm{~h}$ later for ITM, and $24 \mathrm{~h}$ later for LTM. Pups were only tested at one time point in order to avoid possible memory extinction effect. Testing procedures are described elsewhere (Langdon et al. 1997; Price et al. 1998; McLean et al. 1999).

\section{Immunohistochemistry}

Ten minutes following odor training, pups were sacrificed by perfusion using $4 \%$ paraformaldehyde. Immunohistochemistry was performed on olfactory bulb sections cut coronally at $30 \mu \mathrm{m}$ using a Leica cryostat, as described previously (McLean et al. 1993, 1999). Antibodies examined included pCREB (phosphorylated at Ser 133, 1/1000 dilution, Millipore) and pERK (phosphorylated p44/42 at Thr202/Tyr204, 1/500-1/1000 dilution, Cell Signaling).

\section{Image analysis}

Immunohistochemically stained sections were viewed using a Leica microscope attached to a Leica camera. Software with the camera provided even illumination of the field and the light level was kept at the same level throughout the analysis with an optimal optical density reading. The medial side of adjacent sections was analyzed quantitatively. For pERK, the external plexiform layer was chosen as the region of interest (ROI) because dendritic-like label appeared densest in the deepest portion of that layer while the olfactory nerve layer was chosen as background. For pCREB, the mitral cell layer was chosen as the ROI because staining was mainly nuclear and that layer was found to show significant increase with pCREB expression in early learning while the olfactory nerve layer served as background (McLean et al. 1999). Relative optical density was determined by optical density (OD, 0-255 scale) of background minus ROI divided by OD of background.

\section{Acknowledgments}

We thank Joseph P. Clarke for help with graphic presentations. This work was supported by a grant to J.H.M. and C.W.H. from CIHR (MOP 53761).

\section{References}

Abel T, Nguyen PV. 2008. Regulation of hippocampus-dependent memory by cyclic AMP-dependent protein kinase. Prog Brain Res 169: $97-115$.

Aflaki M, Qi XY, Xiao L, Ordog B, Tadevosyan A, Luo X, Maguy A, Shi Y, Tardif JC, Nattel S. 2014. Exchange protein directly activated by cAMP mediates slow delayed-rectifier current remodeling by sustained $\beta$-adrenergic activation in guinea pig hearts. Circ Res 114: 993-1003.

Alberini CM. 1999. Genes to remember. J Exp Biol 202: 2887-2891.

Attramadal H, Arriza JL, Aoki C, Dawson TM, Codina J, Kwatra MM, Snyder SH, Caron MG, Lefkowitz RJ. 1992. $\beta$-arrestin2, a novel member of the arrestin/ $\beta$-arrestin gene family. J Biol Chem 267: 17882-17890.

Bozon B, Kelly A, Josselyn SA, Silva AJ, Davis S, Laroche S. 2003. MAPK, CREB and zif 268 are all required for the consolidation of recognition memory. Philos Trans R Soc Lond B Biol Sci 358: 805-814.

Cheung U, Atwood HL, Zucker RS. 2006. Presynaptic effectors contributing to cAMP-induced synaptic potentiation in Drosophila. J Neurobiol 66: $273-280$.

Christensen AE, Selheim F, de Rooji J, Dremier S, Schwede F, Dao KK, Martinez A, Maenhaut C, Bos JL, Genieser HG, et al. 2003. cAMP analog mapping of Epac1 and cAMP kinase. Discriminating analogs demonstrate that Epac and cAMP kinase act synergistically to promote PC-12 cell neurite extension. J Biol Chem 278: 35394-35402.

Christie-Fougere MM, Darby-King A, Harley CW, McLean JH. 2009. Calcineurin inhibition eliminates the normal inverted $U$ curve, enhances acquisition and prolongs memory in a mammalian $3^{\prime}-5^{\prime}$-cyclic AMP-dependent learning paradigm. Neuroscience 158: $1277-1283$.

Cui W, Smith A, Darby-King A, Harley CW, McLean JH. 2007. A temporal-specific and transient cAMP increase characterizes odorant classical conditioning. Learn Mem 14: 126-133.

Cui W, Darby-King A, Grimes MT, Howland JG, Wang YT, McLean JH, Harley CW. 2011. Odor preference learning and memory modify GluA1 phosphorylation and GluA1 distribution in the neonate rat olfactory bulb: testing the AMPA receptor hypothesis in an appetitive learning model. Learn Mem 18: 283-291.

de Rooij J, Zwartkruis FJ, Verheijen MH, Cool RH, Nijman SM, Wittinghofer A, Bos JL. 1998. Epac is a Rap1 guanine-nucleotideexchange factor directly activated by cyclic AMP. Nature 396: 474-477.

Duvarci S, Nader K, LeDoux JE. 2005. Activation of extracellular signal-regulated kinase- mitogen-activated protein kinase cascade in the amygdala is required for memory reconsolidation of auditory fear conditioning. Eur J Neurosci 21: 283-289.

Eckel-Mahan KL, Phan T, Han S, Wang H, Chan GC, Scheiner ZS, Storm DR. 2008. Circadian oscillation of hippocampal MAPK activity and 
cAMP: implications for memory persistence. Nat Neurosci 11: $1074-1082$

Enserink JM, Christensen AE, de Rooij J, van Triest M, Schwede F, Genieser HG, Doskeland SO, Blank JL, Bos JL. 2002. A novel Epac-specific cAMP analogue demonstrates independent regulation of Rap1 and ERK. Nat Cell Biol 4: 901-906.

Favata MF, Horiuchi KY, Manos EJ, Daulerio AJ, Stradley DA, Feeser WS, Van Dyk DE, Pitts WJ, Earl RA, Hobbs F, et al. 1998. Identification of a novel inhibitor of mitogen-activated protein kinase kinase. J Biol Chem 273: 18623-18632.

Ferrero JJ, Alvarez AM, Ramírez-Franco J, Godino MC, Bartolomé-Martín D, Aguado C, Torres M, Luján R, Ciruela F, Sánchez-Prieto J. 2013. $\beta$-Adrenergic receptors activate exchange protein directly activated by cAMP (Epac), translocate Munc13-1, and enhance the Rab3A-RIM1 $\alpha$ interaction to potentiate glutamate release at cerebrocortical nerve terminals. J Biol Chem 288: 31370-31385.

Ganesh A, Bogdanowicz W, Haupt M, Marimuthu G, Rajan KE. 2010. Role of olfactory bulb serotonin in olfactory learning in the greater short-nosed fruit bat, Cynopterus sphinx (Chiroptera: Pteropodidae). Brain Res 1352: 108-117.

Gelinas JN, Banko JL, Peters MM, Klann E, Weeber EJ, Nguyen PV. 2008. Activation of exchange protein activated by cyclic-AMP enhances long-lasting synaptic potentiation in the hippocampus. Learn Mem 15: 403-411.

Grandoch M, Roscioni SS, Schmidt M. 2010. The role of Epac proteins, novel cAMP mediators, in the regulation of immune, lung and neuronal function. Br J Pharmacol 159: 265-284.

Grimes MT, Smith M, Li X, Darby-King A, Harley CW, McLean JH. 2011. Mammalian intermediate-term memory: new findings in neonate rat. Neurobiol Learn Mem 95: 385-391.

Grimes MT, Harley CW, Darby-King A, McLean JH. 2012. PKA increases in the olfactory bulb act as unconditioned stimuli and provide evidence for parallel memory systems: pairing odor with increased PKA creates intermediate- and long-term, but not short-term, memories. Learn Mem 19: $107-115$

Harley CW, Darby-King A, McCann J, McLean JH. 2006. $\beta 1$-adrenoceptor or $\alpha 1$-adrenoceptor activation initiates early odor preference learning in rat pups: support for the mitral cell/cAMP model of odor preference learning. Learn Mem 13: 8-13.

Izquierdo LA, Barros DM, Ardenghi PG, Pereira P, Rodrigues C, Choi H, Medina JH, Izquierdo I. 2000. Different hippocampal molecular requirements for short- and long-term retrieval of one-trial avoidance learning. Behav Brain Res 111: 93-98.

Josselyn SA, Nguyen PV. 2005. CREB, synapses and memory disorders: past progress and future challenges. Curr Drug Targets CNS Neurol Disord 4: 481-497.

Kanellopoulos AK, Semelidou O, Kotini AG, Anezaki M, Skoulakis EM. 2012. Learning and memory deficits consequent to reduction of the fragile $\mathrm{X}$ mental retardation protein result from metabotropic glutamate receptor-mediated inhibition of cAMP signaling in Drosophila. J Neurosci 32: 13111-13124.

Kawai HD, La M, Kang HA, Hashimoto Y, Liang K, Lazar R, Metherate R. 2013. Convergence of nicotine-induced and auditory-evoked neural activity activates ERK in auditory cortex. Synapse 67: 455-468.

Kawasaki H, Springett GM, Mochizuki N, Toki S, Nakaya M, Matsuda M, Housman DE, Graybiel AM. 1998. A family of cAMP-binding proteins that directly activate Rap1. Science 282: 2275-2279.

Keiper M, Stope MB, Szatkowski D, Bohm A, Tysack K, Vom DF, Saur O, Oude Weernink PA, Evellin S, Jakobs KH, et al. 2004. Epac- and $\mathrm{Ca}^{2+}$-controlled activation of Ras and extracellular signal-regulated kinases by Gs-coupled receptors. J Biol Chem 279: 46497-46508.

Kelleher RJ, Govindarajan A, Jung HY, Kang H, Tonegawa S. 2004. Translational control by MAPK signaling in long-term synaptic plasticity and memory. Cell 116: 467-479.

Kelly A, Laroche S, Davis S. 2003. Activation of mitogen-activated protein kinase/extracellular signal-regulated kinase in hippocampal circuitry is required for consolidation and reconsolidation of recognition memory. I Neurosci 23: $5354-5360$.

Kelly MP, Stein JM, Vecsey CG, Favilla C, Yang X, Bizily SF, Esposito MF, Wand G, Kanes SJ, Abel T. 2009. Developmental etiology for neuroanatomical and cognitive deficits in mice overexpressing $\mathrm{G} \alpha$, a G-protein subunit genetically linked to schizophrenia. Mol Psychiatry 14: $398-415,347$.

Lamprecht R, Hazvi S, Dudai Y. 1997. cAMP response element-binding protein in the amygdala is required for long- but not short-term conditioned taste aversion memory. J Neurosci 17: 8443-8450.

Landers MS, Sullivan RM. 2012. The development and neurobiology of infant attachment and fear. Dev Neurosci 34: 101-114.

Langdon PE, Harley CW, McLean JH. 1997. Increased $\beta$ adrenoceptor activation overcomes conditioned olfactory learning deficits induced by serotonin depletion. Brain Res Dev Brain Res 102: 291-293.
Lin SL, Johnson-Farley NN, Lubinsky DR, Cowen DS. 2003. Coupling of neuronal 5-HT7 receptors to activation of extracellular-regulated kinase through a protein kinase A-independent pathway that can utilize Epac. J Neurochem 87: 1076-1085.

Lisman J, Schulman H, Cline H. 2002. The molecular basis of CaMKII function in synaptic and behavioural memory. Nat Rev Neurosci 3: $175-190$.

Logan DW, Brunet LJ, Webb WR, Cutforth T, Ngai J, Stowers L. 2012. Learned recognition of maternal signature odors mediates the first suckling episode in mice. Curr Biol 22: 1998-2007.

Ma N, Abel T, Hernandez PJ. 2009. Exchange protein activated by cAMP enhances long-term memory formation independent of protein kinase A. Learn Mem 16: 367-370.

Mangmool S, Shukla AK, Rockman HA. 2010. $\beta$-Arrestin-dependent activation of $\mathrm{Ca}^{2+} /$ calmodulin kinase II after $\beta_{1}$-adrenergic receptor stimulation. J Cell Biol 189: 573-587.

Mani BK, Chuang JC, Kjalarsdottir L, Sakata I, Walker AK, Kuperman A, Osborne-Lawrence S, Repa JJ, Zigman JM. 2014. Role of calcium and EPAC in norepinephrine-induced ghrelin secretion. Endocrinology 155: 98-107.

McLean JH, Darby-King A, Sullivan RM, King SR. 1993. Serotonergic influence on olfactory learning in the neonate rat. Behav Neural Biol 60: $152-162$.

McLean JH, Harley CW, Darby-King A, Yuan Q. 1999. pCREB in the neonate rat olfactory bulb is selectively and transiently increased by odor preference-conditioned training. Learn Mem 6: 608-618.

McLean JH, Smith A, Rogers S, Clarke K, Darby-King A, Harley CW. 2009. A phosphodiesterase inhibitor, cilomilast, enhances cAMP activity to restore conditioned odor preference memory after serotonergic depletion in the neonate rat. Neurobiol Learn Mem 92: $63-69$.

McPhee I, Gibson LC, Kewney J, Darroch C, Stevens PA, Spinks D, Cooreman A, MacKenzie SJ. 2005. Cyclic nucleotide signalling: a molecular approach to drug discovery for Alzheimer's disease. Biochem Soc Trans 33: $1330-1332$.

Miller SG, Kennedy MB. 1986. Regulation of brain type $\mathrm{II} \mathrm{Ca}^{2+} /$ calmodulin-dependent protein kinase by autophosphorylation: a $\mathrm{Ca}^{2+}$-triggered molecular switch. Cell 44: 861-870.

Mirich JM, Illig KR, Brunjes PC. 2004. Experience-dependent activation of extracellular signal-related kinase (ERK) in the olfactory bulb. J Comp Neurol 479: 234-241.

Moriceau S, Shionoya K, Jakubs K, Sullivan RM. 2009. Early-life stress disrupts attachment learning: the role of amygdala corticosterone, locus ceruleus corticotropin releasing hormone, and olfactory bulb norepinephrine. J Neurosci 29: 15745-15755.

Morrison GL, Fontaine CJ, Harley CW, Yuan Q. 2013. A role for the anterior piriform cortex in early odor preference learning: evidence for multiple olfactory learning structures in the rat pup. J Neurophysiol 110: $141-152$.

Nijholt IM, Dolga AM, Ostroveanu A, Luiten PG, Schmidt M, Eisel UL. 2008. Neuronal AKAP150 coordinates PKA and Epac-mediated PKB/Akt phosphorylation. Cell Signal 20: 1715-1724.

Ohno M, Frankland PW, Chen AP, Costa RM, Silva AJ. 2001. Inducible, pharmacogenetic approaches to the study of learning and memory. Nat Neurosci 4: 1238-1243.

Ostroveanu A, Van der Zee EA, Dolga AM, Luiten PG, Eisel UL, Nijholt IM. 2007. A-kinase anchoring protein 150 in the mouse brain is concentrated in areas involved in learning and memory. Brain Res 1145: $97-107$.

Ouyang M, Zhang L, Zhu JJ, Schwede F, Thomas SA. 2008. Epac signaling is required for hippocampus-dependent memory retrieval. Proc Natl Acad Sci 105: 11993-11997.

Park SW, Roohbakhsh A, Beninger RJ. 2014. 8-pCPT, an Epac activator, impairs conditioned place preference based on nucleus accumbens amphetamine in rats. Acta Neuropsychiatr 26: 104-111.

Penzes P, Srivastava DP, Woolfrey KM. 2009. Not just actin? A role for dynamic microtubules in dendritic spines. Neuron 61: 3-5.

Price TL, Darby-King A, Harley CW, McLean JH. 1998. Serotonin plays a permissive role in conditioned olfactory learning induced by norepinephrine in the neonate rat. Behav Neurosci 112: $1430-1437$

Raineki C, Pickenhagen A, Roth TL, Babstock DM, McLean JH, Harley CW, Lucion AB, Sullivan RM. 2010. The neurobiology of infant maternal odor learning. Braz J Med Biol Res 43: 914-919.

Renaudineau S, Poucet B, Laroche S, Davis S, Save E. 2009. Impaired long-term stability of CA1 place cell representation in mice lacking the transcription factor zif268/egr1. Proc Natl Acad Sci 106: $11771-11775$.

Rich RC, Schulman H. 1998. Substrate-directed function of calmodulin in autophosphorylation of $\mathrm{Ca}^{2+} /$ calmodulin-dependent protein kinase II. J Biol Chem 273: 28424-28429. 
Roberson ED, English JD, Adams JP, Selcher JC, Kondratick C, Sweatt JD. 1999. The mitogen-activated protein kinase cascade couples PKA and PKC to cAMP response element binding protein phosphorylation in area CA1 of hippocampus. J Neurosci 19: 4337-4348.

Rumsey JD, Darby-King A, Harley CW, McLean JH. 2001. Infusion of the metabotropic receptor agonist, DCG-IV, into the main olfactory bulb induces olfactory preference learning in rat pups. Brain Res Dev Brain Res 128: $177-179$.

Schafe GE, LeDoux JE. 2000. Memory consolidation of auditory pavlovian fear conditioning requires protein synthesis and protein kinase $\mathrm{A}$ in the amygdala. J Neurosci 20: RC96.

Schafe GE, Nadel NV, Sullivan GM, Harris A, LeDoux JE. 1999. Memory consolidation for contextual and auditory fear conditioning is dependent on protein synthesis, PKA, and MAP kinase. Learn Mem 6: 97-110.

Sharma SK, Sherff CM, Shobe J, Bagnall MW, Sutton MA, Carew TJ. 2003. Differential role of mitogen-activated protein kinase in three distinct phases of memory for sensitization in aplysia. J Neurosci 23: 3899-3907.

Silva AJ, Kogan JH, Frankland PW, Kida S. 1998. CREB and memory. Annu Rev Neurosci 21: 127-148.

Srivastava DP, Woolfrey KM, Jones KA, Anderson CT, Smith KR, Russell TA, Lee H, Yasvoina MV, Wokosin DL, Ozdinler PH, et al. 2012. An autism-associated variant of Epac2 reveals a role for Ras/Epac2 signaling in controlling basal dendrite maintenance in mice. PLoS Biol 10: $\mathrm{e} 1001350$.

Ster J, De Bock F, Guérineau NC, Janossy A, Barrère-Lemaire S, Bos JL, Bockaert J, Fagni L. 2007. Exchange protein activated by cAMP (Epac) mediates cAMP activation of p38 MAPK and modulation of $\mathrm{Ca}^{2+}$-dependent $\mathrm{K}^{+}$channels in cerebellar neurons. Proc Natl Acad Sci 104: $2519-2524$.

Sullivan RM, McGaugh JL, Leon M. 1991. Norepinephrine-induced plasticity and one-trial olfactory learning in neonatal rats. Brain Res Dev Brain Res 60: 219-228.

Sullivan RM, Stackenwalt G, Nasr F, Lemon C, Wilson DA. 2000. Association of an odor with activation of olfactory bulb noradrenergic $\beta$-receptors or locus coeruleus stimulation is sufficient to produce learned approach responses to that odor in neonatal rats. Behav Neurosci 114: $957-962$.

Wang X, Wang ZH, Wu YY, Tang H, Tan L, Wang X, Gao XY, Xiong YS, Liu D, Wang JZ, et al. 2013. Melatonin attenuates scopolamine-induced memory/synaptic disorder by rescuing EPACs/miR-124/Egr1 pathway. Mol Neurobiol 47: 373-381.

Witkowski G, Rola R, Szulczyk P. 2012. Effect of cyclic adenosine monophosphate on the $\mathrm{G}$ protein-dependent inward rectifier $\mathrm{K}(+)$-like channel current in medial prefrontal cortex pyramidal neurons. $J$ Physiol Pharmacol 63: 457-462.
Wolman MA, de Groh ED, McBride SM, Jongens TA, Granato M, Epstein JA. 2014. Modulation of cAMP and ras signaling pathways improves distinct behavioral deficits in a zebrafish model of neurofibromatosis type 1. Cell Rep 8: 1265-1270.

Woolfrey KM, Srivastava DP, Photowala H, Yamashita M, Barbolina MV, Cahill ME, Xie Z, Jones KA, Quilliam LA, Prakriya M, et al. 2009. Epac2 induces synapse remodeling and depression and its disease-associated forms alter spines. Nat Neurosci 12: 1275-1284.

Yang E, Schulman H. 1999. Structural examination of autoregulation of multifunctional calcium/calmodulin-dependent protein kinase II. J Biol Chem 274: 26199-26208.

Yang Y, Shu X, Liu D, Shang Y, Wu Y, Pei L, Xu X, Tian Q, Zhang J, Qian K, et al. 2012. EPAC null mutation impairs learning and social interactions via aberrant regulation of miR-124 and Zif268 translation. Neuron 73: $774-788$.

Yuan Q, Harley CW, Bruce AJ, Darby-King A, McLean JH. 2000. Isoproterenol increases CREB phosphorylation and olfactory nerve-evoked potentials in normal and 5-HT-depleted olfactory bulbs in rat pups only at doses that produce odor preference learning. Learn Mem 7: 413-421.

Yuan Q, Harley CW, Darby-King A, Neve RL, McLean JH. 2003. Early odor preference learning in the rat: bidirectional effects of cAMP response element-binding protein (CREB) and mutant CREB support a causal role for phosphorylated CREB. J Neurosci 23: $4760-4765$.

Zaldua N, Gastineau M, Hoshino M, Lezoualc'h F, Zugaza JL. 2007. Epac signaling pathway involves STEF, a guanine nucleotide exchange factor for Rac, to regulate APP processing. FEBS Lett 581: $5814-5818$

Zhang JJ, Okutani F, Inoue S, Kaba H. 2003. Activation of the mitogen-activated protein kinase/extracellular signal-regulated kinase signaling pathway leading to cyclic AMP response element-binding protein phosphorylation is required for the long-term facilitation process of aversive olfactory learning in young rats. Neuroscience 121: 9-16.

Zhang HT, Zhao Y, Huang Y, Dorairaj NR, Chandler LJ, O’Donnell JM. 2004. Inhibition of the phosphodiesterase 4 (PDE4) enzyme reverses memory deficits produced by infusion of the MEK inhibitor U0126 into the CA1 subregion of the rat hippocampus. Neuropsychopharmacology 29: $1432-1439$

Zhong N, Zucker RS. 2005. cAMP acts on exchange protein activated by cAMP/cAMP-regulated guanine nucleotide exchange protein to regulate transmitter release at the crayfish neuromuscular junction. $J$ Neurosci 25: 208-214.

Received September 26, 2014; accepted in revised form November 6, 2014. 


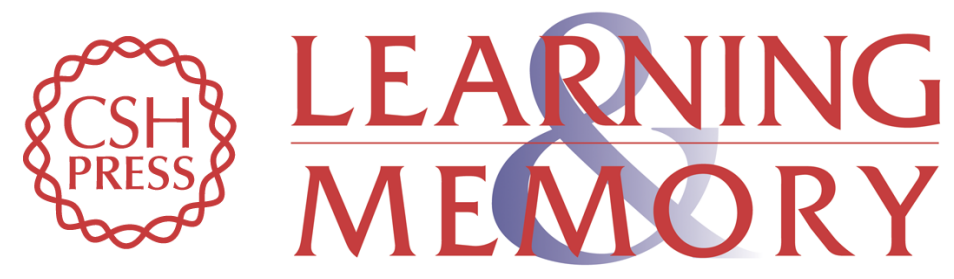

\section{Epac activation initiates associative odor preference memories in the rat pup}

Matthew T. Grimes, Maria Powell, Sandra Mohammed Gutierrez, et al.

Learn. Mem. 2015, 22:

Access the most recent version at doi:10.1101//m.037101.114

References This article cites 80 articles, 32 of which can be accessed free at: http://learnmem.cshlp.org/content/22/2/74.full.html\#ref-list-1

Creative This article is distributed exclusively by Cold Spring Harbor Laboratory Press for the Commons License first 12 months after the full-issue publication date (see http://learnmem.cshlp.org/site/misc/terms.xhtml). After 12 months, it is available under a Creative Commons License (Attribution-NonCommercial 4.0 International), as described at http://creativecommons.org/licenses/by-nc/4.0/.

Email Alerting Receive free email alerts when new articles cite this article - sign up in the box at the Service top right corner of the article or click here. 